\title{
Scalariella a new genus of monoraphid diatom (Bacillariophyta) with a bipolar distribution
}

\author{
Catherine RiauX-Gobin*1, Andrzej WitKowski ${ }^{2} \&$ Manfred RupPel ${ }^{3}$ \\ ${ }^{1}$ Laboratoire d'Excellence "CORAIL", USR 3278, CNRS-EPHE, CRIOBE- Perpignan University FR-66086 \\ Perpignan, France; *corresponding author e-mail: catherine.gobin@univ-perp.fr, tel: 33 (0)4 686617 01, fax: \\ $33(0) 468503686$ \\ ${ }^{2}$ Palaeoceanology Unit, University of Szczecin, Mickiewicza 18, PL-70-383 Szczecin, Poland \\ ${ }^{3}$ Fachbereich Biowissenschaften Goethe-Universität Frankfurt, D-60054 Frankfurt am Main, Germany
}

\begin{abstract}
The identity of a small-celled diatom Naviculadicta pseudofallacia WitKowski, Metzeltin et LangeBERTALOT, originally described from Bear Island, southernmost island of the Norwegian archipelago Svalbard, is reconsidered. Observations of marine samples from the Kerguelen archipelago (Southern Ocean, Indian Ocean sector) revealed that this species also occurs in the Subantarctic region. The original classification within Naviculadicta was erroneous since this species is a monoraphid taxon and belongs to the Achnanthales. Its morphological features justify creating a new genus Scalariella RIAUX-GoBIN, which is distinguished from other achnanthoid genera by a peculiar raphe system, the stria structure of the sternum valve (each stria composed of a depressed macroareola), and the presence of a lateral solid area in the raphe valve, splitting each stria into two areolae. Based on light and electron microscopy, N. pseudofallacia is renamed Scalariella pseudofallacia (Witkowski, Metzeltin et Lange-Bertalot) RiauX-Gobin et WitKowski comb. nov. The genus also includes a second and rare species, observed in the Kerguelen material, S. oblongella RiauX-Gobin, WitKowsKi et RuPpel, which is described and illustrated, but which needs complementary observations. The morphology of Scalariella is compared to that of some genera split from the genus Achnanthes BORY. The biogeography of Scalariella pseudofallacia, a marine taxon probably misidentified in the past due to its small size, is reconsidered with respect to its affinity for subpolar, cold water habitats, in both hemispheres.
\end{abstract}

Key words: diatoms, Achnanthales, Scalariella gen. nov., S. pseudofallacia comb. nov., S. oblongella sp. nov., morphology, geographic distribution

\section{Introduction}

Naviculadicta pseudofallacia WitKowski, Metzeltin el Lange-Bertalot (Metzeltin \& WitKowsKi 1996) is a small-celled marine diatom first described as a member of the genus Naviculadicta Lange-Bertalot (Lange-BertaLOT \& Moser 1994). N. pseudofallacia originated from the Bear Island in Sub-Arctic. The authors based their description on light and electron microscopy (SEM and TEM) observations. Naviculadicta was proposed as a taxon to hold a number of established or new taxa with morphological characters that excluded them from Navicula sensu stricto after other genera were separated from Navicula sensu lato (e.g. Cox 1987; Mann 1989; Mann \& Stickle 1991; Round et al. 1990). Although the genus Naviculadicta was subsequently criticized by KoCIOLEK (1996), it continues to be used (e.g. Metzeltin \& WitKowsKi 1996; Lange-Bertalot \& Genkal 1999; Van de ViJver et al. 2002; Metzeltin et al. 2005).

In the present report we demonstrate that Naviculadicta pseudofallacia is a heterovalvar, monoraphid diatom, belonging to the Achnanthales sensu Silva (1962). Its sternum valve (SV) was first observed during a survey of the genus Cocconeis from the Kerguelen Archipelago (Indian Ocean, Austral sector; RIAUX-GobIN \& ROMERo 2003). It was subsequently found again in some other Kerguelen samples from the same survey (WitKowski et al., pers. obs.).

The inclusion of this taxon in an existing genus appeared difficult, since several characteristics, or groups of characteristics, do not fit any existing genus. As part of the Achnanthales, the large and heterogeneous genus Achnanthes BORY has been subdivided, 
beginning in 1990, with the aim of creating smaller, homogeneous genera. Although Round et al. (1990) re-erected Achnanthidium KüTZING, and Eucocconeis CLEVE, further splitting was strongly advocated by two authors: BuKHTIYAROVA and Round. Bukhtiyarova \& Round (1996) and Round \& Bukhtiyarova (1996) redifined Achnanthidium and established several new genera, e.g. Psammothidium Bukhtiyarova et Round, Rossithidium Round et Bukhtiyarova, Planothidium Round et BuKhtIYARova, Karayevia Round et BukhtiYarova and Kolbesia Round et Bukhtiyarova. Subsequently, some Achnanthes taxa have been transferred to Eucocconeis (Lange-Bertalot \& Genkal 1999; see also Krammer \& Lange-Bertalot 2004). Finally it was proposed that Kolbesia be united to Karayevia (BuKHTIYAROVA 2006).

A group of taxa resembling Achnanthes bahusiensis was moved to another new genus Astartiella Witkowski, Lange-Bertalot et Metzeltin (WitKowski 1998), Achnanthes taeniata into the new genus Pauliella Round et BAsson, and Achnanthes hungarica into Lemnicola Round et BASSON (Round \& BASSON 1997). Recently BukHTIYAROVA (2008) summarized the subdivision of Achnanthes sensu lato. Despite major efforts by several research groups (e.g. Round et al. 1990; BuKHTIYAROVA \& Round 1996; Round \& BuKhtiyarova 1996; LANGE-Bertalot \& GeNKAL 1999; WitKowski et al. 2000; Krammer \& LANGE-Bertalot 2004; Diaz \& Maidana 2006), there are still numerous taxa that are either unique or constitute small clusters of taxa which need appropriate generic classification. This is the case for $N$. pseudofallacia and another similar taxon which we describe as a new species.

In this paper we describe Scalariella, a new genus of monoraphid diatoms, which includes a previously established species, i.e. Naviculadicta pseudofallacia. We characterize the genus based on light (LM) and electron microscopy [scanning (SEM) and transmission (TEM)]. A second, rare taxon (Table 1), belonging to the same genus and also discovered in Kerguelen is described and illustrated in SEM. We re-evaluate the biogeographic range of Scalariella pseudofallacia and the morphological characteristics of the new genus are compared to those of several achnanthoid genera, with a particular focus on Karayevia sensu lato (Table 2). Although several of these genera (Table 2) are exclusively fresh-water (such as Nupela), morphological comparisons can be made.

Another small-celled taxon, still classified under Achnanthes, i.e. A. delicatissima Simonsen (HINZ et al., in press), shows some characteristics close to those of Scalariella (Table 1) but also to Achnanthidium sensu lato (Round et al. 1990). Its type material is examined, illustrated and compared to Scalariella.

\section{Material and Methods}

Sediment samples were collected during four austral summers between 1985 and 1992 at different marine Kerguelen stations. The Archipelago is located to the north of the "Plateau des Kerguelen", between $49^{\circ}$ and $50^{\circ} \mathrm{S}$, near the Polar Front (see map in RiauX-GobiN \& RoMERo 2003). All sediment samples (intertidal and subtidal) were formalin preserved ( $10 \%$ final dilution). A variety of habitats were sampled (from subtidal muds underlying the macroalgal belt, to exposed intertidal sandy beaches or estuarine shallow mud) and epipsammic, epipelic and epiphytic diatoms collected.

The monoraphid diatoms, some of which are of epiphytic origin (impressive Macrocystis pyrifera belts inhabit shores and fjords), are numerous on the subtidal shallow muds of Kerguelen. Two sites (see fig. A and table 2 in Riaux-Gobin \& Romero 2003) were regularly sampled in the Morbihan Bay: Port-AuxFrançais (12 m water depth; $49^{\circ} 20^{\prime} \mathrm{S}, 69^{\circ} 50^{\prime} \mathrm{E}$ ) and Port-Raymond (10 m water depth; $49^{\circ} 21^{\prime} \mathrm{S}, 70^{\circ} 12^{\prime}$ E). In addition the holotype of $N$. pseudofallacia was analyzed (slide No. 40-1 in Coll. Lange-Bertalot, Senckenberg Museum, Frankfurt am Main). Original material of A. delicatissima (Simonsen 1959, the western Baltic Sea) was also observed under LM and SEM.

For LM examination, the sediment was rinsed with distilled water, cleaned with concentrated $\mathrm{H}_{2} \mathrm{O}_{2}$, rinsed again with distilled water, gently centrifuged, alcohol-dehydrated, air-dried onto cover glasses, and mounted in Naphrax ${ }^{\circledR}$. A Leica DM LB Photomicroscope, equipped with a PlanAPO x100 (i.d. 1.4) objective and Nikon camera (University of Szczecin, Poland), was used for slides observation.

For SEM examination, samples were collected onto $1 \mu \mathrm{m}$ Nuclepore filters, rinsed twice with deionised water (milliQ) and air-dried. The filters were then mounted on stubs and coated with goldpalladium alloy using a sputter coater (EMSCOP SC 500 apparatus), and examined with a SEM НITACHI S-4500, operating at $10 \mathrm{kV}$ (C2M University of Perpignan Via Domitia, France and the Botanical Institute of the J.-W. Goethe-University, Frankfurt am Main, Germany). The apparatus in Frankfurt am Main has been operating at $5-7 \mathrm{kV}$ and the stubs were coated with gold (Agar-Sputter-Coater). Since no severe treatment was applied to the samples, the intact valve's 
hymenes can be observed in SEM examination.

\section{Results}

\section{Scalariella RiauX-Gobin gen. nov.}

Diagnosis: Valvae ellipticae ad oblongae-ellipticae, apicibus obtuse rotundis.

Sternumvalva: valva leniter convexa. Area axialis recta et moderate angusta. Striae transapicales parallelae, ad modice radiantes ad polos. Areolae latae, in totis striis locatae et marginem attingentes, hymeno delicato occlusae. Area centralis nulla.

Raphevalva : valva plana ad leniter concava. Raphe recta filiformis, extremis centralibus approximatis et parum deflectis ad primarium latus. Fissurae terminales duplo curvatae et ad idem latus deflectae. Area axialis anguste linearis. Striae moderate radiantes, cum aequalibus interstriis et in media parte interruptae a lunatis areis lateralibus apices non attingentibus.

Typus generis: Scalariella pseudofallacia (WITKOWSKI, Metzeltin et Lange-Bertalot) Riaux-Gobin et WITKOWSKI comb. nov.

Description: Heterovalvar and solitary diatom. Observed on marine sediments. Valves elliptic to linear elliptic with obtusely rounded to subrostrate apices.

Sternum valve (SV) convex, transapical striae in parallel rows in the central part of the valve to very slightly radiate in the apices (Figs $7-9,1-2,5)$. Striae formed of wide, very slightly depressed, scalar apertures or macroareolae (following the definition by BukHTIYAROva 2006) and occluded internally by a thin hymen without apparent slits (Fig. 6). Narrow linear sternum.

Raphe valve (RV) flat to very slightly concave, striae parallel at the centre of the valve to radiate at the apices (Figs 10-17). Striae regularly spaced. A hyaline lateral lunate-shaped area, not reaching the apices, divides the striae into two large and regular areolae/foramina (Figs 10-17). Areolae occluded by a thin uniform hymen (without visible slits, Fig. 17; see also TEM illustration in Metzeltin \& WitKowsKi 1996, tafel 76, fig. 9), not domed internally (Figs 14-16). Externally, there are two lateral sunken recesses in the hymenes of the marginal areolae (Fig. 17, arrow). Axial area narrow and internally raised (Fig. 16). Central area almost absent. Raphe filiform and straight, central raphe endings small and rounded, relatively close externally and very slightly bent to the primary side, coaxial internally (Fig. 15). Terminal raphe fissures double-hooked and deflected to the same side (Figs 12, 13, 17), opposite to that of the central endings. Relatively poorly developed helictoglossae (Fig. 15). Girdle is composed of several non-perforated bands (Figs 11, 12, 16), with a wavy valvocopula to the RV (Fig. 16, arrow).

Etymology: the generic name makes reference to ladder-like (scalar) appearance of the almost parallel, regularly spaced, SV striae.

Remarks: similitude to other achnanthoid diatoms, but with several distinctive features: 1) central raphe endings internally coaxial, 2) terminal raphe fissures strongly double-hooked, 3) hymen occluding the macroareolae without apparent slits, but with marginal recesses, 4) no central area, 5) presence of a hyaline, lunate-shaped, lateral area on each side of the RV (Table 1), dividing the individual areola of each stria into two (never more than two).

\section{Scalariella pseudofallacia (WITKOWSKI,} Metzeltin et Lange-Bertalot) Riaux-Gobin et Witkowski comb. nov. [Figs 7-9 (LM), Figs 1-6; 10-17 (SEM)]

Basionym: Naviculadicta pseudofallacia WiтKOwski, Metzeltin et Lange-Bertalot, in Metzeltin \& WiткошSкі 1996, Iconographia Diatomologica 4, p. 23, figs $50 / 20-21,76 / 9-12$

See p. 23, figs 50/20-21, 76/9-12, 79/4, 85/8 in Metzeltin \& Witkowski 1996, for the RV. Also illustrated in pl 69/19 in WiткоwsKi et al. 2000.

Holotype: praep. Bären-Insel No. 40-1, in FRA, Coll. Lange-Bertalot, Senckenberg Museum, Frankfurt am Main, Germany.

Description: See genus diagnosis for the general description of the frustule. Small-celled taxon, length: $5-10.5 \mu \mathrm{m}$; width: $2.5-5 \mu \mathrm{m}$. The SV striae are easily resolved in LM (Figs 7-9; specimens from Kerguelen). The $\mathrm{SV}$ is characterized by non-radiate, transapical, regular, wide, subparallel striae, open externally (Figs 1,2,5), with rounded ends near the border of the valve and the sternum. Narrow, linear axial area. The RV has radiate striae and a narrow axial area. Central raphe endings relatively close and slightly turned to primary side (e.g. Figs 10-17), internally coaxial (Fig. 15). Terminal raphe fissures strongly double-hooked on same side (Fig. 13). A TEM illustration (Metzeltin \& WitKowsKi 1996, tafel 76, fig. 9) of a specimen from Bear Island confirms the doubly hooked terminal raphe fissure, the very thin internal hymenes with no apparent slits, and the undecorated area crossing each stria in the centre. Girdle composed of several (up to four) 


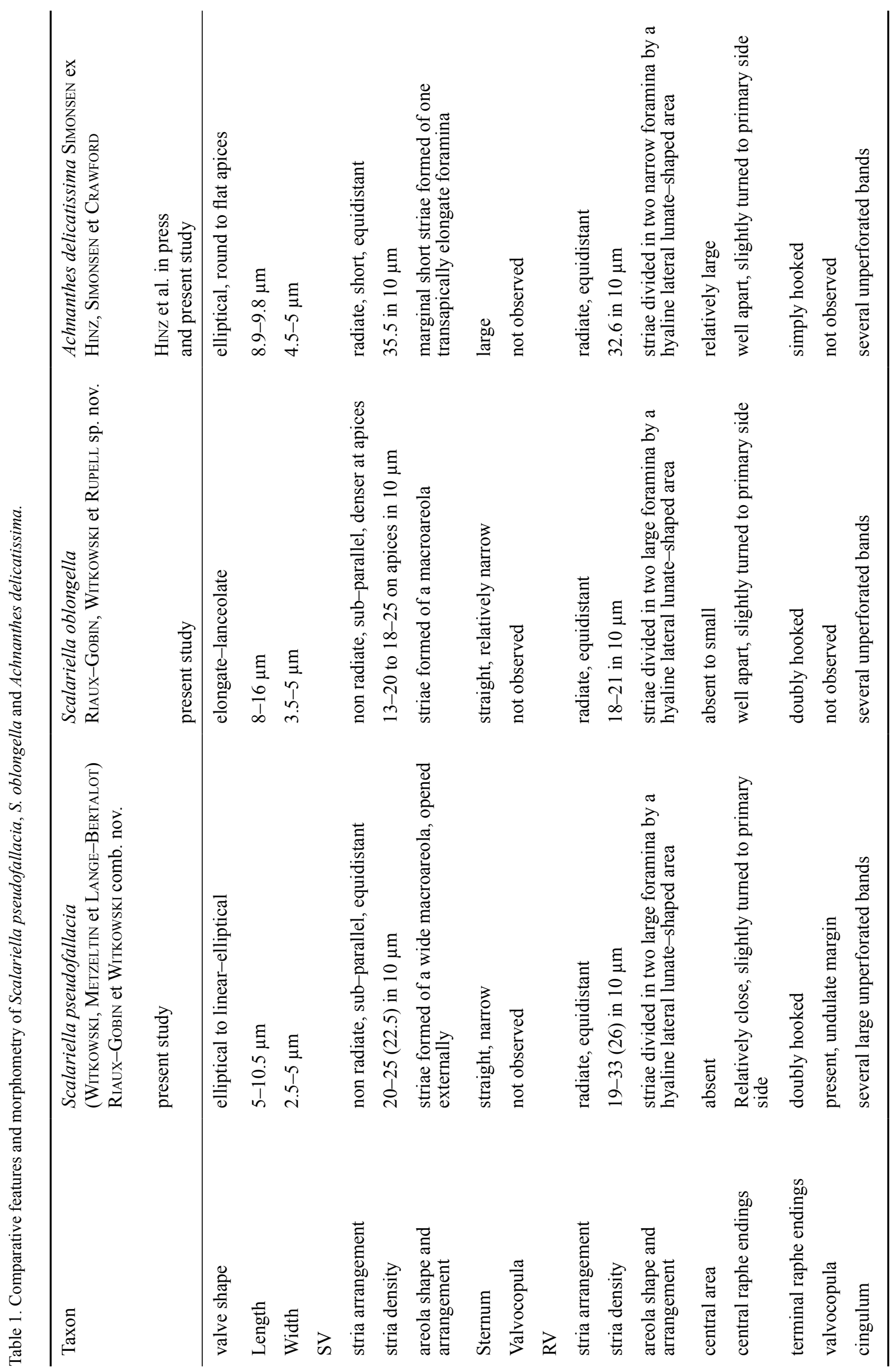




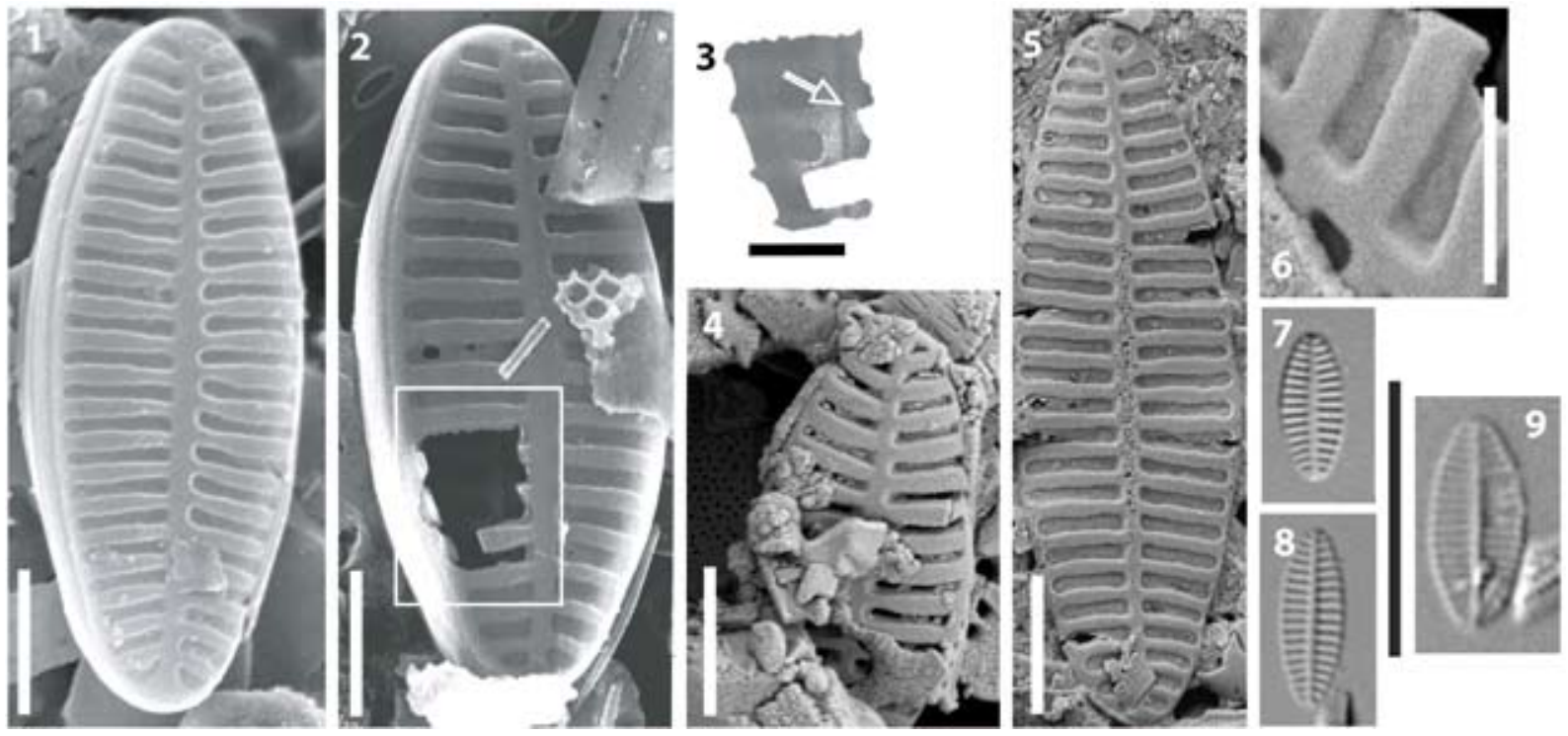

Figs 1-9. Scalariella pseudofallacia from Kerguelen Islands: (7-9) LM, Scale bar $10 \mu \mathrm{m}$; SEM, Scale bars $2 \mu \mathrm{m}$ (Figs 1-2, 4-5); $1 \mu \mathrm{m}$ (Figs 3, 6). Scalariella pseudofallacia (1-2, 4-5) external views of sternum valve (SV) showing striation composed of an unique foramen or macroareola; (3) magnification of the square-detail of Fig. 2, showing the raphe valve (RV) with the raphe (framed arrow); (6) detail of macroareolae, with depressed hymen without slits; (7-9) SV in LM.

open bands (see MetZeltin \& WitKowski 1996; tafel 76, fig. 10). A valvocopula with a wavy margin was observed on one RV specimen from Kerguelen (Fig. 16), confirming the previous observations from Bear Island (Metzeltin \& WiTKOWSKI 1996; tafel 76, fig. 10). Approximately the same stria density on both valves (cf. Fig. 2 illustrating a broken specimen showing both valves, and Fig. 11 also showing both valves): SV with 20-25 (mean 22.5) striae in $10 \mu \mathrm{m}$; RV with 19-33 (mean 26) striae in $10 \mu \mathrm{m}$. Striae regularly spaced on each valve. Large range of stria density per specimen observed.

Distribution: unfrequent but not rare.

LM and SEM material: Specimens from marine sediments off Kerguelen.

Habitat: found in intertidal marine sediments from the main Kerguelen island

Ecology/ethology: Scalariella pseudofallacia was observed as solitary cells, never in chains. Found on marine sediments, but never attached to sand grains. Previously reported as N. pseudofallacia in Bear Island and the Norwegian Sea, near Narvik (Metzeltin \& Witkowski 1996; Witkowski et al. 2000).

\section{Scalariella oblongella RIAUX-GobIN, WitKowSKI et RuPPEL sp. nov. [Figs 18-20 (SEM)]}

Diagnosis: Valvae oblongae-lanceolatae, 8-16 longae, 3.5-5 $\mu$ m latae, apicibus obtuse rotundis.

Sternumvalva: Area axialis recta et moderate angusta. Striae transapicales parallelae in medio valvae (13-20 in $10 \mu \mathrm{m})$, densiores ad polos (18-25 in $10 \mu \mathrm{m})$, ex areolis magnis factae, hymeno delicato clausis.

Raphevalva : valva plana ad leniter concava. Raphe directa filiformis, extremis centralibus distincte deflectis ad primarium latus. Fissurae terminales duplo curvatae. Area axialis anguste linearis, area centralis leniter inflata. Striae modice radiantes (18-21 in 10 $\mu \mathrm{m})$, in media parte interruptae cum areis lateralibus. Habitat sedimentum marinum Kerguelense.

Description: Valve elongate-lanceolate with obtusely round apices

Sternum valve (Figs 18, arrow; Fig. 20, internal view): striae parallel $(13-20$ in $10 \mu \mathrm{m})$ at centre of valve, denser towards the apices (18-25 in 10 $\mu \mathrm{m})$. Each stria, in SV and RV, is composed of a unique large areola/foramen occluded by a thin hymen. Sternum regular and straight, slightly raised internally (Fig. 20).

Raphe valve: raphe filiform. Axial area narrow, very slightly enlarged in median part. Central raphe endings small and externally deflected towards the primary side (Fig. 19). Striae regularly spaced on the whole valve $(18-21$ in $10 \mu \mathrm{m})$, interrupted by a lateral regular hyaline space. Terminal raphe fissures double-hooked (Fig. 19). Transapical striae parallel in the middle of the valve and slightly radiate on apices. Cingular bands present but not observed precisely.

Note: only three specimens were observed in SEM.

Distribution: rare, Bossière intertidal (see map in RiaUX-Gobin \& Romero 2003; site $n^{\circ} 5$ in Fig. A) 


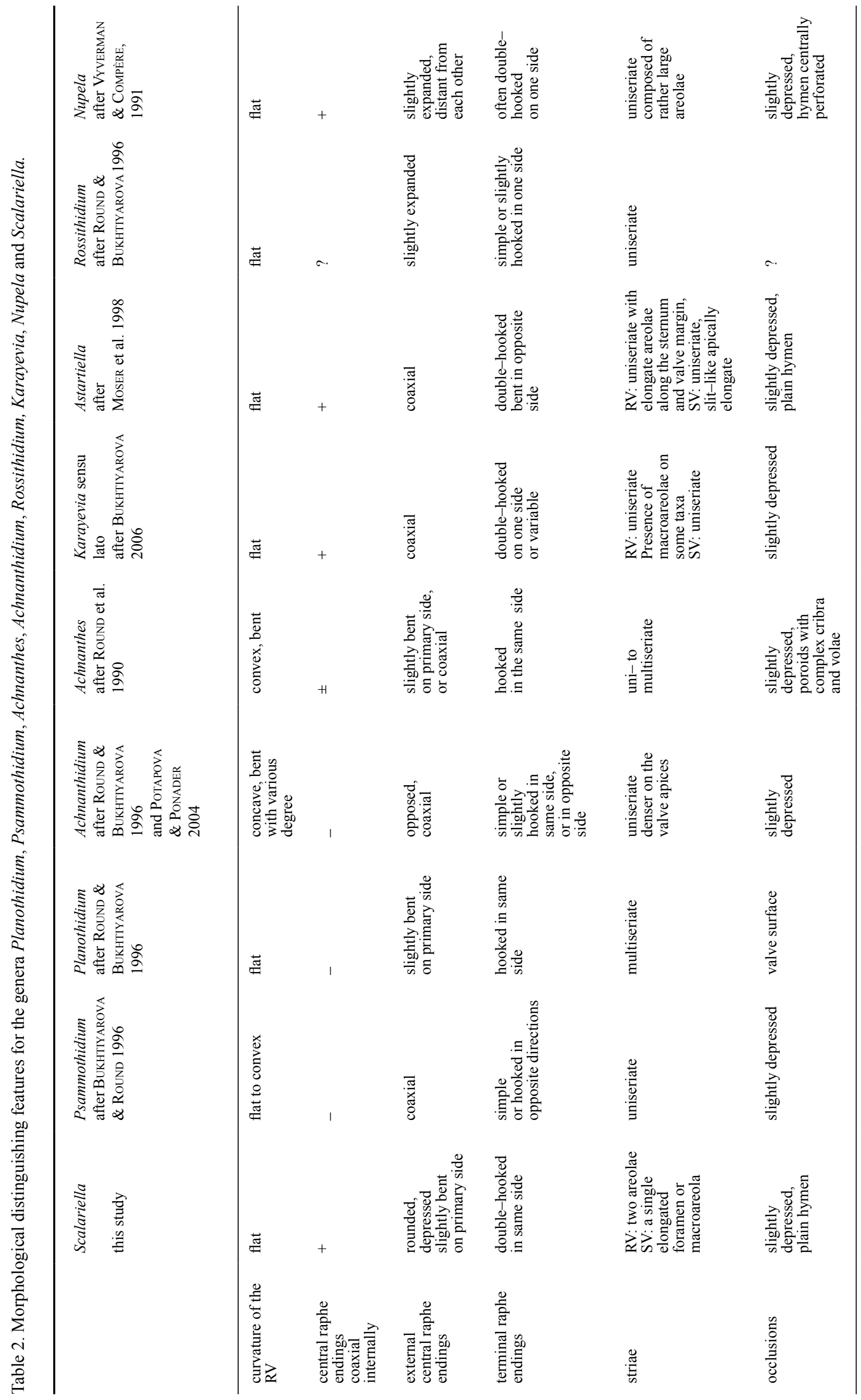




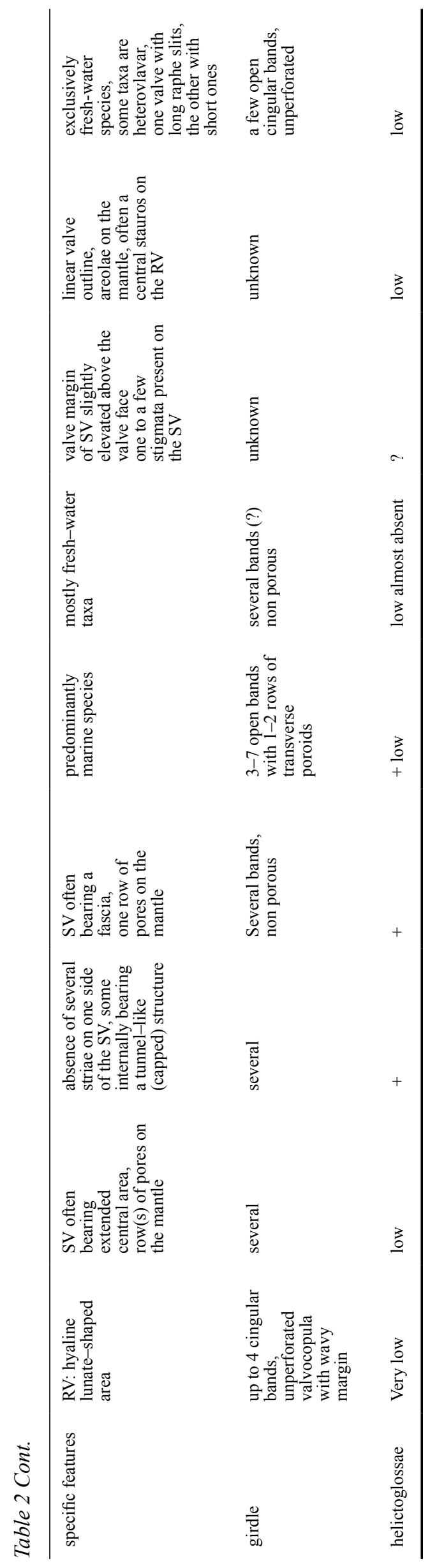

Holotype: SEM stub B8, in Collection Horst LANGE-Bertalot (Frankfurt am Main, Germany at the J.W-Goethe University, FRA), illustrated by the SEM Fig. 19.

Isotype: Slide 7356/10 housed at A. WitKowSKI Collection at the Institute of Marine Sciences, University of Szczecin (SZCZ).

Holotype locality: "Port Raymond subtidal" (see map in RiauX-Gobin \& Romero 2003; site $\mathrm{n}^{\circ} 3$ in Fig. A). Sample "Port Raymond subtidal" in Collection RiauX-Gobin (USR 3278 CNRSEPHE, CRIOBE-Perpignan University, France). Etymology: the epithet refers to the shape of the valve.

Habitat: found in intertidal marine sediments from the main Kerguelen island

Remarks: shows all distinctive features of Scalariella. LM and more SEM illustrations are needed before a more complete description can be given (external view of the SV, internal view of the RV, and copulae).

\section{Discussion}

Comparison of Scalariella with other monoraphid genera, particularly Karayevia and Nupela

The morphological characteristics of the new genus Scalariella and other genera established after Achnanthes BORY sensu lato was first subdivided, are compared in Table 2. Several of these characteristics are not constant or may vary within a genus, such as the terminal raphe fissures, which may be either simple or hooked (i.e. in Achnanthidium and Psammothidium), or the structure of the striae, i.e. uni- to multiseriate. None of these new genera can be defined simply, using only a few criteria, except for Nupela whose areola pattern (with a round central hole on the hymen) seems unique (Vyverman \& COMPÈre 1991). Nevertheless, these recently established genera allow numerous taxa to be classified, although the position of several others remains uncertain, pending study with SEM, as proposed by BuKHTIYAROVA \& Round (1996) and Round \& BukHTIYAROVA (1996).

When observed with LM, Scalariella most closelyresembles Planothidium orPsammothidium (e.g. Buktiyarova \& Round 1996; Witkowski et al. 2000; Krammer \& Lange-Bertalot 2004). The general valve outline and the pattern of striae in both valves are relatively similar in 
these genera. The most striking LM feature that differentiates Scalariella from Planothidium and Psammothidium is the lack of a central area in the $\mathrm{RV}$ of the first genus.

However, SEM and TEM images reveal that the ultrastructure of Scalariella is completely different from that of the other genera (Table 2), particularly with respect to stria and raphe ultrastructure. The SV transapical striae comprise one scalar elongated areola/foramen, or macroareola (BukHTIYAROVA 2006), per stria opening externally (Figs 4-5, 7-9), and internally closed by a flat (or very slightly domed) thin hymen. A major difference is also observed around the RV areolae: our study shows that only two large and regular areolae, covered by a thin flat hymen, occur in Scalariella, and that both raphe endings are double-hooked in the same direction. The combination of these features is unique and it is difficult to classify our taxon under the genera cited in Table 2.

It should be noted that striae composed of one, slightly depressed, macroareola on the valve face, is a characteristic shared by several biraphid genera, such as Diadesmis, Chamaepinnularia [e.g. C. mediocroformis (Coste et RICARD) LANGEBertalot; in Moser et al. 1998, tafel 32, fig. 11], Gomphosphenia [e.g. G. oahuensis (HUSTEDT) LANGe-Bertalot; in Moser et al. 1998, tafel 53, fig. 2], Navicula(dicta) schmassmanii Hustedt (Werum \& Lange-Bertalot 2004, plate 34) and the recently created Microfissurata (CANTONATI
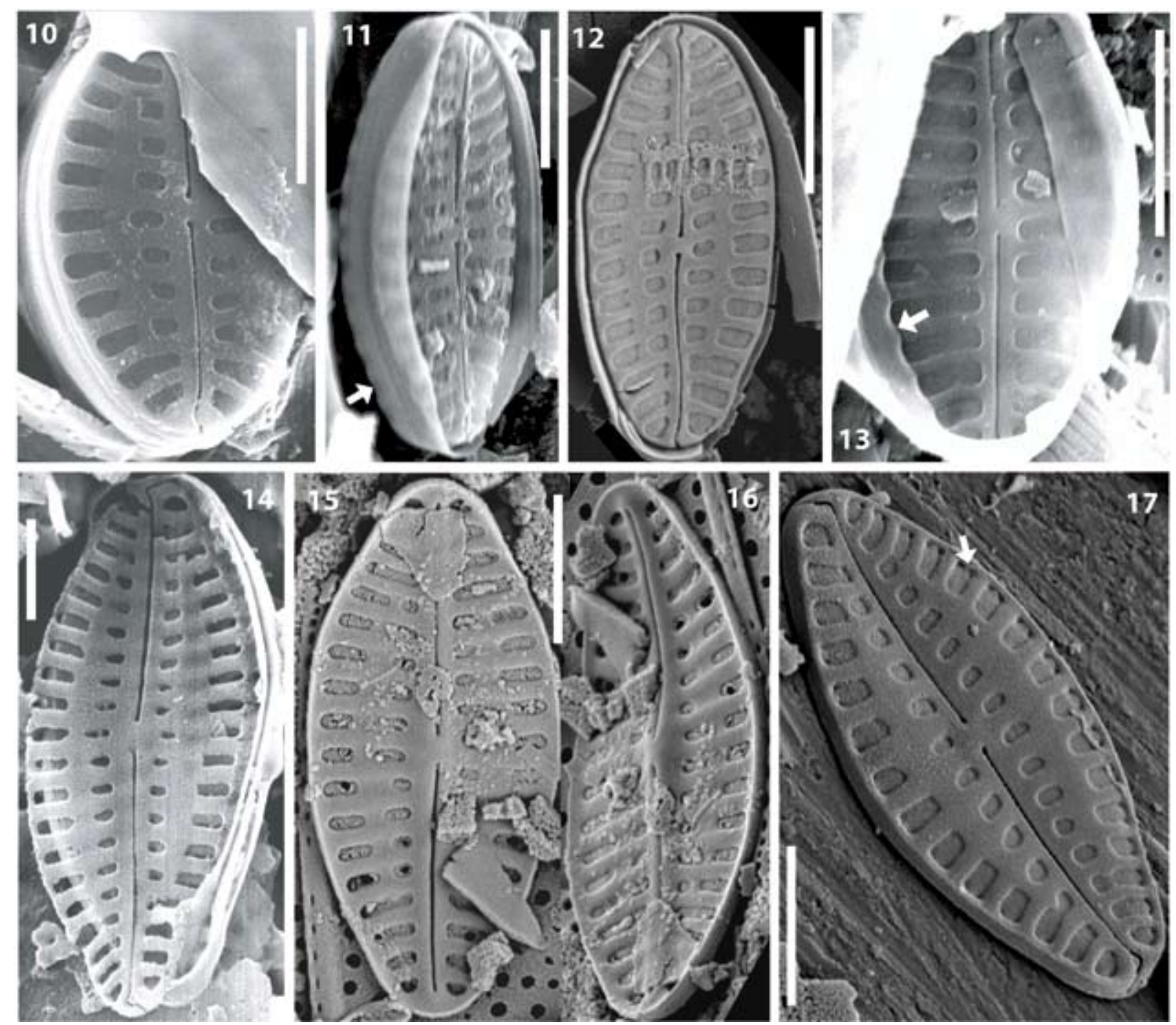

Figs 10-17. Scalariella pseudofallacia from Kerguelen Islands: Scale bars $2 \mu \mathrm{m}$. SEM specimens from Kerguelen (Figs 10-17). Scalariella pseudofallacia $(10-13,17)$ external views of the RV showing the hyaline lunate-shaped interruption of the striae, the raphe endings and the copulae. The arrow in Fig. 11 shows the striation of the slightly convex SV; (14-16) internal views of the RV showing the central raphe endings and the poorly developed helictoglossae; (16) internal view of the RV showing the wavy valvocopula (arrow); $(13,17)$ apical raphe ending doubly hooked. 

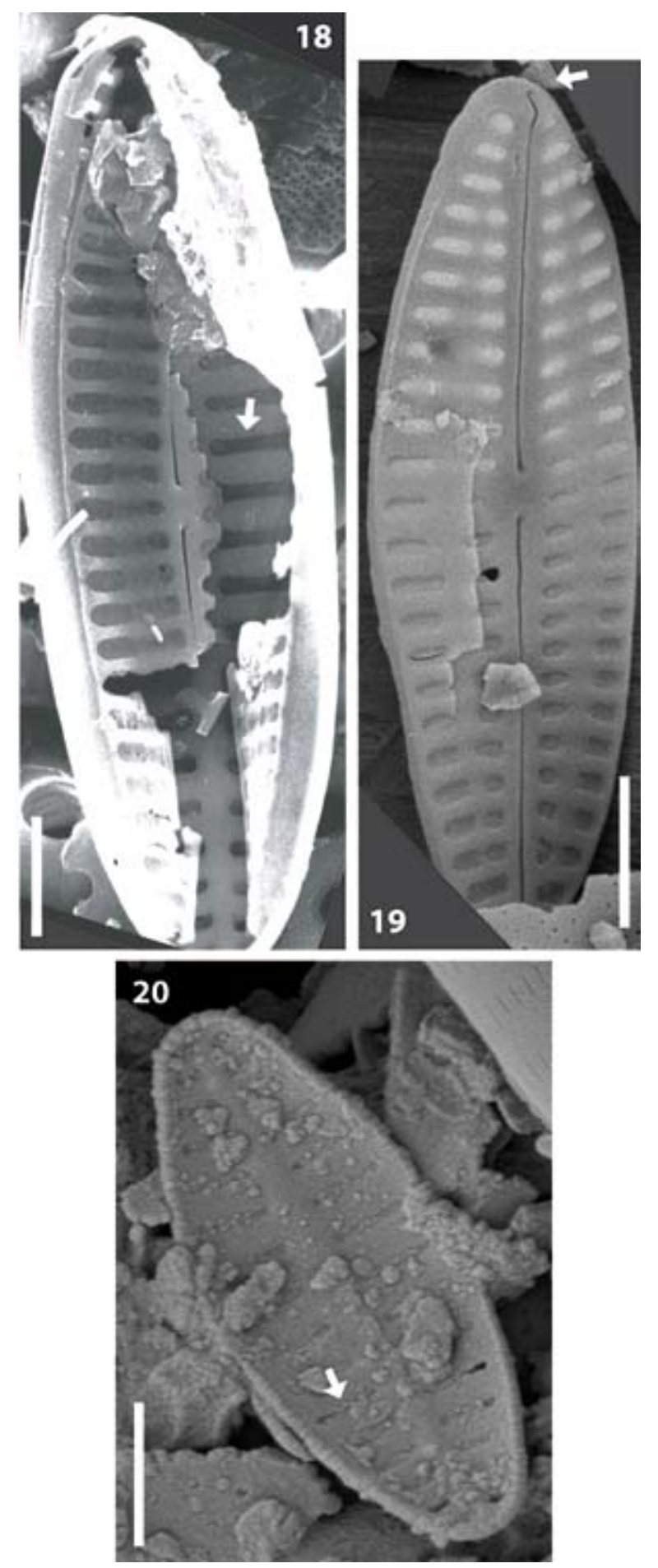

Figs 18-20. Scalariella oblongella from Kerguelen Islands: (18-20) SEM. Scale bars $2 \mu \mathrm{m}$. SEM specimens from Kerguelen. Scalariella oblongella (18-20) SEM, external views of the RV showing the hyaline lunate-shaped interruption of the striae, the raphe doubly hooked ending (19, arrow). The arrow in Fig. 18 shows the striation of the SV, denser on apices. (20) SEM, internal view of the SV with striation denser on apices and a slightly raised sternum. Note that the macroareolae (arrow) are not reaching the margin of the valve. et al. 2009; fig. 1, j). But for most of these taxa, a row of oblong foramina is also present on the mantle, which is lacking in Scalariella.

Within the Achnanthales, several taxa have striae composed of a macroareola (shown in SEM) on both valves. For example: A. carissima LANGEBertalot (Lange-Bertalot \& Krammer 1989, tafel 38, figs 1-4). This taxon has a row of short foramina on the RV mantle, simple terminal raphe endings and several apical slits on each valve. A. dornii Lange-Bertalot (LAnge-Bertalot \& KRAMMER 1989, tafel 38, figs 5-7) has simply deflected terminal raphe endings. The two taxa have been transferred to the genus Karayevia (BukhtiYarova 2006).

Several other taxa show the characteristic stria pattern only on their RV: e.g. Karayevia kolbei (Hustedt) BuKhtiYARova, previously named Kolbesia kolbei (Hustedt) Round et BUKHTIYAROVA, has more than two foramina on the SV and one on the mantle (Round \& BuKhtIYAROVA 1996, figs 20-21), and hooked terminal raphe endings (ibid, fig. 22). Achnanthes laterostrata HUSTEDT transferred to Karayevia (Lange-Bertalot \& Krammer 1989, tafel 44, figs 6, 7; BukhtiYarova 2006, figs 9-12). Karayevia suchlandtii (Hustedt) BuKhtiYarova [BuKhtIYAROVA 2006, figs 13, 14, 16; previously named Kolbesia suchlandtii (Hustedt) J.C. KingSTON].

The term of macroareola (for stria formed of a single foramen) and postmacroareola (stria formed of several "short macroareolae"), established by BukHTIYAROVA (1996), permits her to define the genus Karayevia as containing "primitive features" (macroareolae on both valves, i.e. in $K$. carissima) and "progressive features" (postmacroareolae on both valves, i.e. in K. clevei). However, the Karayevia group appears highly heterogeneous, concerning: 1) the presence or absence of foramina on the SV mantle, 2) the raphe ending path (simple in K. carissima while the primitive feature would be hooked endings, BUKHTIYAROVA 2006), and 3) the great range of variation in complexity of the SV areolae (simple elongated foramina in Karayevia kolbei, to complex areolae with rota-type pore occlusions in Karayevia clevei).

The stria pattern of $K$. kolbei $\mathrm{SV}$, as illustrated in BukHtiYAROva (2006) [fig. 20, very different from previous illustrations in Round \& BuKhtiYARova (1996, figs 20-21, with several elongate foramina)] could match that of 
Scalariella pseudofallacia, except for the row of elongate foramina on the mantle, which is lacking in Scalariella. However, the RV of Scalariella is completely different from that of $K$. kolbei and does not match any Karayevia sp.

Some similarities can also be seen between Scalariella and Nupela Vyverman et COMPÈRE. Nupela is a biraphid diatom (VYverman \& COMPÈRE 1991), although hetereovalvy was recently demonstrated for some of its species (Potapova et al. 2003; Siver et al. 2007). We note that the Scalariella RV shows great similarity with respect to the raphe system of several Nupela spp. [e.g. N. neglecta Ponader, Lowe et Potapova and $N$. carolina Potapova et Clason (Potapova et al. 2003), N. silvahercynia (LANGe-BERTALOT) Lange-Bertalot, $N$. lapidosa (Krasske) LangeBertalot (Werum \& Lange-Bertalot 2004)].

\section{Some similarities with Achnanthes delicatissima Simonsen ex Hinz, Simonsen et Crawford}

A previous observation by A.W. of unmounted material of Achnanthes delicatissima SIMONSEN (ex Hinz, Simonsen et Crawford; see Hinz et al., in press) [sampled on 20.07.1955 (SIMONSEN 1959) from Sahrensdorfer Binnensee, Burgstacken $(0.8 \mathrm{~m})$, the type locality], and observation of the holotype slide Di-208, gave the opportunity to establish some similarities between the latter taxon and Scalariella. Features and morphometry of A. delicatissima are reported and compared to those of Scalariella species in Table 1. The LM and particularly the SEM illustrations of $A$. delicatissima (Figs 21-27) show some similitude within the RV of this taxon and that of Scalariella: the striae are split in two parts by a hyaline lunateshaped area that does not reach the apices, each stria part being an oblong depressed foramina. That morphology is quite similar to that in Scalariella, except for the thickness of the striae (thinner in
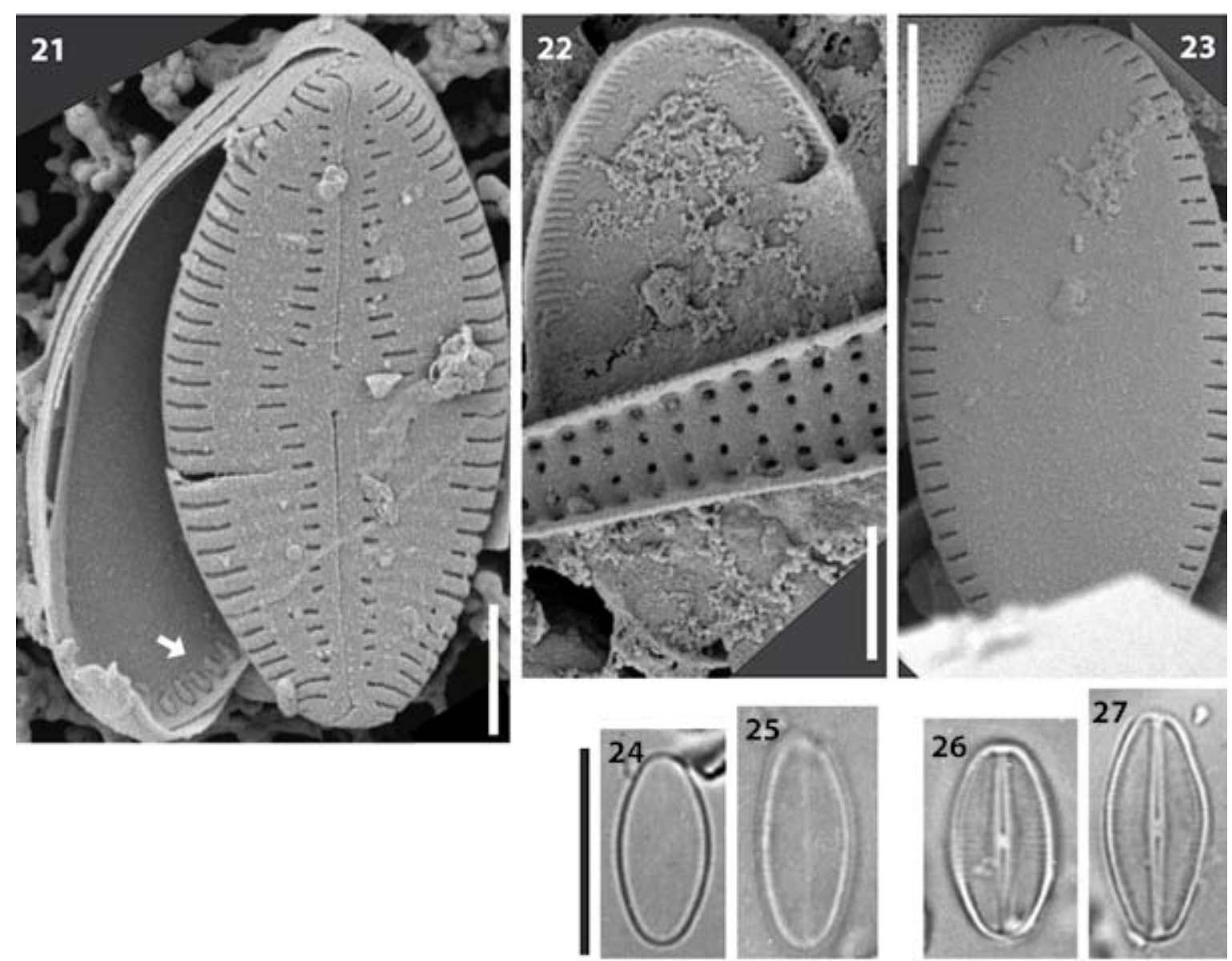

Figs 21-27. Achnanthes delicatissima [unmounted type material from Sahrensdorfer Binensee, Burgstacken (0.8 m), sampled on 20.07.1955 (Simonsen 1959), and holotype slide Di-208]: (21-23) SEM. Scale bars $2 \mu \mathrm{m}$. (24-27) LM. Scale bar $10 \mu \mathrm{m}$. Achnanthes delicatissima (21) external view of the raphe valve (RV) showing striation interrupted by a hyaline area and elongated areolae; (21-22) showing the internal view of the SV, with short marginal striae; (23) external view of the SV; (24-27) LM images of entire frustules (24-25) and of RV (26-27). 
A. delicatissima). However, A. delicatissima has a slightly expanded, rounded central area on the $\mathrm{RV}$ and the terminal raphe endings are simply deflected and not double-hooked. Furthermore the $\mathrm{SV}$ of $A$. delicatissima is very dissimilar to that of Scalariella, with an extremely wide sternum and very short, strongly radiate, marginal striae, also around the apices, with internally domed hymenes (Figs 21-22). The later remarks permit to state that A. delicatissima cannot pertain to Scalariella.

On the other hand, it can be noticed that a species of Achnanthidium sensu lato (Round et al. 1990), recently found in coral sediments off Mascarenes (RIAUX-Gobin et al., in press), has features very similar to that of Achnanthes delicatissima, except a higher stria density on both valves (33-57 on the SV and 46-80 on the RV). Another tropical taxon, Achnanthidium pseudochamaepinnularia RIAUX-GoBIN et al. (2010), has also some similarities with Achnanthes delicatissima but $A$. pseudochamaepinnularia has a denser striation and dissimilar stria density on both valves (30-41 on the SV and $40-50$ on the RV). The design of the SV striae is also different (much longer and irregular in $A$. pseudochamaepinnularia).

Following Hinz et al. (in press), $A$. delicatissima is now a valid species of Achnanthes sensu lato. Nevertheless, the latter taxon, as well as several species found on coral reefs off Mascarenes (e.g. Achnanthidium pseudochamaepinnularia and Achnanthidium sp., RIAUX-GoBIN et al., in press), with their very specific features (Table 1), may be transferred later on to an other genus.

It can also be remarked that $A$. fogedii HÅKANSSON is a later synonym of $A$. delicatissima (see HAKAnsson 1978, e.g. figs D-F). $A$. delicatissima occurs in the Adriatic and Baltic Seas (SIMONSEN 1959) as A. fogedii (HÁKANSSON 1978; WunsAm et al. 1999; WITKOWSKI et al. 2000), and in Holocene saline lake sediments (Salziger See, Central Germany; SzYLKIEwICz 2006).

\section{Biogeography}

Naviculadicta pseudofallacia was described from Bear Island $\left(74^{\circ} 30^{\prime}-74^{\circ} 20^{\prime} \mathrm{N}\right.$; half way between northern Norway and south of Spitsbergen) (Metzeltin \& Witkowski 1996). Two LM illustrations (MetzeLtin \& WitKowski 1996, pl. 76/11-12) come from examination of the slide $\mathrm{N}^{\circ} 1669$ of the Østrup Collection (Copenhagen) collected from the coast of Greenland. In WitKOWSKI et al. (2000), the locality of Narvik is indicated for the same taxon (Norwegian Sea; $68^{\circ} 26^{\prime} 00 \mathrm{~N} ; 7^{\circ} 25^{\prime} 00 \mathrm{E}$, north of the Polar circle). Recently SEIDLER (2004) and Nagumo et al. (2008) found $S$. pseudofallacia in subfossil sediments of Benicia State Park (San Francisco Bay) salt marshes and (as Achnanthes sp. 1, LM and SEM figures) in water pumped from $218 \mathrm{~m}$ deep in Shiretoko Rausu, Okhotsk Sea, respectively. NAGUmo et al. (2008) also found S. pseudofallacia as an epiphyte among the attached diatom flora.

The new finding of $S$. pseudofallacia in the Southern hemisphere may indicate that this genus was misidentified in the past, and may be a rather widespread taxon on the sub-polar (cold water) environments of both hemispheres. Further investigation is needed to describe the exact biogeography of this small-celled taxon and that of $S$. oblongella, second species of this genus, for which more specimens need to be studied to understand its features better.

Our knowledge on the distribution of marine littoral diatom species suggests that bipolar distribution is not very common. There are a few other examples. e.g. Fragilariopsis cylindrus (Grunow ex Cleve) Frenguelli, F. nana (Steemann Nielsen) PaAsche (e.g. Lundholm \& Hasle 2008; PIKE et al. 2008). Otherwise, littoral marine diatoms more commonly have a very broad geographic distribution, e.g. Odontella aurita (Lyngbye) C. A. Agardh, Planothidium delicatulum (KüTZING) Round et BuKhTIYAROvA, Catenula adhaerens Mereschkowsky, Navicula gregaria Donkin, Paralia sulcata (EHRENBerg) Cleve, and Nitzschia ligowskii WitKowski, LANGeBertalot, Kociolek et Brzezinska (WitKowski et al. 2000; WitKowsKI et al. 2004).

The new genus Scalariella, now comprises two small-sized species from the Kerguelen material, but $S$. pseudofallacia is known from other localities (see above), and valves with a lunate hyaline area on each side of the RV, and scalar striae composed of macroareolae on the SV, may have been misidentified in the past, and will probably be found in other environments, polar or otherwise.

\section{Acknowledgments}

C. R.-G. thanks the over-wintering team members and crew of the RV "La Japonaise" for their field assistance at Kerguelen Islands. We are grateful to Dimitri Gorand (C2M, Perpignan University Via Domitia). We acknowledge the help of Friedel Hinz, from Alfred Wegener Institute in Bremerhaven, for the loan of 
Simonsen unmounted material and the holotype of $A$. delicatissima, and for her warning about the validation of several Simonsen taxa (HINZ et al., in press). Many thanks also to Karen K. Serieyssol for her help, and to Pierre Compère for his alert about the non-availability of the name Scalaria, previously given to our new genus, and for his critical remarks on the manuscript. Critical reading of the manuscript by an anonymous reviewer and valuable comments by Patrick Kociolek were appreciated. We also thank Sigurd von Boletzky (UMR 7628, Fr-Banyuls-sur-Mer) and the anonymous reviewer for their Latin diagnosis improvement. Funds and logistic assistance in the field were supported by the "Terres Australes et Antarctiques Françaises" (TAAF). This study was supported by a grant from Polish Ministry of Science and Higher Education No. N 306468538.

\section{References}

Bukhtiyarova, L.N. (2006): Additional data on the diatom genus Karayevia and a proposal to reject the genus Kolbesia. - Nova Hedwigia Beiheft 130: 85-96.

Bukhtiyarova, L.N. (2008): Revision of the genus Achnanthes Bory s. lato (Bacillariophyta). 2. New monosutural genera and the key for their identification. - Int. J. Algae 10: 50-72.

Bukhtiyarova, L. \& Round, F.E. (1996): Revision of the genus Achnanthes s.l. Psammothidium a new genus based on $A$. marginulatum. - Diatom Res. 11:1-30.

Cantonati, M.; VAn de Vijver, B. \& LangeBertalot, H. (2009): Microfissurata gen. nov. (Bacillariophyta), a new diatom genus from dystrophic and intermittently wet terrestrial habitats. - J. Phycol. 45: 732-741.

Cox, E.J. (1987): Placoneis Mereschkowsky: The reevaluation of a diatom genus originally characterized by its chloroplast type. - Diatom Res. 2: 145-157.

Diaz, C.A. \& Maidana N.I. (2006): A new monoraphid diatom genus: Haloroundia Diaz \& Maidana. Nova Hedwigia Beiheft 130: 177-184.

HÅKAnsson, H.-L. (1978): Achnanthes fogedii, a new subfossil diatom from Sweden. - Bot. Not. 131: 407-408.

Hinz, F.; Simonsen, R. \& CRAwFord, R.M. Validation of forty-four names of diatom taxa from the Baltic Sea. - Diatom Res., in press.

Kociolek, J.P. (1996): Comment: Taxonomic instability and the creation of Naviculadicta Lange-Bertalot in Lange-Bertalot \& Moser, a new catch-all genus of diatoms. - Diatom Res. 11: 219-222.

Krammer, K. \& Lange-Bertalot, H. (2004): Bacillariophyceae. 4. Achnanthaceae, Kritische
Ergänzungen $\mathrm{zu}$ Navicula (Lineolatae) und Gomphonema Gesamtliteraturverzeichnis. - In: Ettl, H.; Gärtner, G.; Gerloff, J.; Heyning, H. \& Mollenhauer, D. (eds): Süsswasserflora von Mitteleuropa 2/4, ed. 2. - 437 pp., G. Fischer Verlag, Stuttgart-New York.

Lange-Bertalot, H. \& Genkal, S.I. (1999): Diatomeen aus Sibirien I. Inseln im Arktischen Ozean (Yugorsky-Shar Strait). - Iconogr. Diatomol. 6: $1-271$.

Lange-Bertalot, H. \& K. Kramer, K. (1989): Achnanthes eine Monographie der Gattung mit Definition der Gattung Cocconeis und Nachträgen $\mathrm{zu}$ den Naviculaceae. - In: Bibliotheca Diatomologica 18. - 393 pp., Cramer Verlag, Stuttgart.

Lange-Bertalot, H. \& Moser, G. (1994): Brachysira. Monographie der Gattung. - In: Bibliotheca Diatomologica 1. - 212 pp., Cramer Verlag, Stuttgart.

LundHolm, N. \& Hasle, G.R. (2008): Are Fragilariopsis cylindrus and Fragilariopsis nana bipolar diatoms? - Morphological and molecular analyses of two sympatric species. - Nova Hedwigia Beiheft 133: 231-250.

Mann, D.G. (1989): The diatom genus Sellaphora: separation from Navicula. - Br. Phycol. J. 24: $1-20$.

Mann, D.G. \& Stickle, A.J. (1991): The genus Craticula. - Diatom Res. 6: 79-107.

Metzeltin, D.; Lange-Bertalot, H. \& GarciaRodriguez, F. (2005): Diatoms of Uruguay compared with other taxa from South America and elsewhere. - Iconogr. Diatomol. 15: $1-736$.

Metzeltin, D. \& Witkowski, A. (1996): Diatomeen der Bären-Insel. Süsswasser-und marine Arten. Iconogr. Diatomol. 4: 2-232.

Moser, G.; Lange-Bertalot, H. \& Metzeltin, D. (1998): Insel der Endemiten: geobotanisches phänomen Neukaledonien. - In: Bibliotheca Diatomologica 38. - 464 pp., Cramer Verlag, Stuttgart.

Nagumo, T.; Suzuki, H.; Watanabe, T.; Fujita, D. \& TANAKA, J. (2008): Attach diatoms In the Shiretoko Rausu deep sea water Japan. - In: JAspricA, N.; CAR, A. \& CALIC, M. (eds): Abstracts of $20^{\text {th }}$ International Diatom Symposium Dubrovnik, 7-13 Sept. 2008. - p. 192.

Pike, J.; Allen, C. S.; Leventer, A.; Stickley, C. E. \& Pudsey, C. J. (2008): Comparison of contemporary and fossil diatom assemblages from the western Antarctic Peninsula. - Marine Micropaleontology 67: 274-287.

Potapova, M.G.; Ponader, K.C.; Lowe, R.L.; Clason, T.A. \& BAHLS, L.L. (2003): Small-celled Nupela species from North America. - Diatom 
Res. 18: 293-306.

RiauX-Gobin, C. \& Romero, O. (2011): Marine Cocconeis Ehrenberg (Bacillariophyceae) species, and related taxa, from Kerguelen's Land (Austral Ocean, Indian Sector). - In: Bibliotheca Diatomologica 47. - 234 pp., Cramer Verlag, Stuttgart.

Riaux-Gobin, C.; Romero, O.E.; Compère, P. \& Al-Handal A.Y:: Small-sized Achnanthales (Bacillariophyta) from coral sands off Mascarenes (Western Indian Ocean). Bibliotheca Diatomologica, in press.

Riaux-Gobin, C.; Witkowski A. \& Compère P. (2010): SEM survey and taxonomic position of smallsized Achnanthidium (Bacillariophyceae) from coral sands off Réunion Island (Western Indian Ocean). - Vie Milieu 60: 157-172.

Round, F.E. \& BAsson, P.W. (1997): A new monoraphid diatom genus (Pogoneis) from Bahrain and the transfer of previously described species $A$. hungarica and $A$. taeniata to new genera. Diatom Res. 12: 71-81.

Round, F.E. \& Bukhtiyarova, L. (1996): Four new genera based on Achnanthes (Achnanthidium) together with a re-definition of Achnanthidium.

- Diatom Res. 11: 345-361.

Round, F.E.; CRAwFord, R.M. \& MANn, D.G. (1990): The Diatoms: biology and morphology of the genera. - 747 pp., Cambridge University Press.

SeIDler, J. (2004): Late Holocene, high resolution record of environmental changes in the San Francisco Bay area salt marshes as revealed by diatom analysis. Master thesis. - 174 pp., University of Szczecin, Szczecin.

Silva, P.C. (1962): "Classification of algae". - In: Lewin, R.A. (ed.): Physiology and Biochemistry of Algae. - pp. 827-837, Academic Press, New York \& London.

SimONSEN, R. (1959): Neue Diatomeen aus der Ostsee I. - Kieler Meeresforsch 15: 74-83.

Siver, P.A.; Hamilton, P.B. \& Morales, E.A. (2007): Notes on the genus Nupela (Bacillariophyceae) including the description of a new species, Nupela scissura sp. nov. and an expanded description of Nulepa paludigena. - Phycol. Res. 55: 125-134.

SZYLKIEWICZ, I. (2006): Environmental changes through Late-Glacial and Holocene as revealed by diatom analysis of Lake Salzigersee sediments in Central Germany. Master Thesis, - 101 pp., University of Szczecin, Szczecin.

Van de Vijver; B.; Frenot, Y. \& Beyens, L. (2002): Freshwater diatoms from Île de la Possession (Crozet Archipelago, Subantarctica). - In: Bibliotheca Diatomologica 46. - 412 pp., Cramer Verlag, Stuttgart.

VyVERMAN, W. \& COMPÈRe, P. (1991): Nupela giluwensis gen. \& spec. nov. A new genus of naviculoid diatoms. - Diatom Res. 6: 175-179.

Werum, M. \& Lange-Bertalot, H. (2004): Diatoms in springs from Central Europe and elsewhere under the influence of hydrogeology and anthropogenic impacts. - Iconogr. Diatomol. 13: $1-480$.

Witkowski, A. (1998): Marine Taxa. - In: Moser, G.; Lange-Bertalot, H. \& Metzeltin, D. (eds): Insel der Endemiten. Geobotanisches Phänomen Neukaledonien.-In: Bibliotheca Diatomologica 38. - pp. 347-381, Cramer Verlag, Stuttgart.

Witkowski, A.; Lange-Bertalot, H. \& Metzeltin, D. (2000): Diatom flora of marine coasts I. Iconogr. Diatomol. 7: 1-925.

Witkowski, A.; LANGe-Bertalot, H.; Kociolek, J.P.; Ruppel, M.; WaWrzyniaK-WydrowsKa, B.; BAK, M. \& BrzezinsKA, A. (2004): Four new species of Nitzschia sec. Tryblionella (Bacillariophyceae) resembling $N$. parvula Wm. Smith. - Phycologia 43: 579-595.

Witkowski, A.; Riaux-Gobin, C. \& DaniszewskaKowalczyK, G. Diatom (Bacillariophyceae) flora of the Austral Islands Kerguelen, with consideration on biogeographic distribution of established and newly described taxa. - Iconogr. Diatomol., in prep.

Wunsam, S.; Schmidt, R. \& Müller, J. (1999): Holocene lake development of two Dalmatian lagoons (Malo and veliko Jezero, Isla of Mljet) in respect to changes in Adriatic Sea level and climate. - Palaeogeog. Palaeoclim. Palaeoecol. 146: 251-282.

(C) Czech Phycological Society (2012)

Received March 3, 2011

Accepted July 27, 2011 